\title{
Unusual natural 9,10-dihydrophenanthrenes from roots of Toona Ciliata
}

\author{
Ian Castro-Gamboa, ${ }^{\mathrm{a}}$ M. Fátima das G. F. da Silva, ${ }^{\text {a }}$ Edson Rodrigues Fo, ${ }^{\mathrm{a}}$ João B.

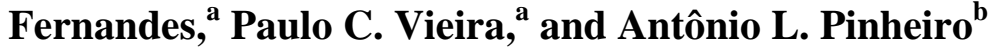

${ }^{a}$ Departamento de Química, Universidade Federal de São Carlos, Caixa Postal 676, 13565-905 São Carlos, SP, Brazil, and ${ }^{b}$ Departamento de Engenharia Florestal, Universidade Federal de Viçosa, 36570-000 Viçosa, MG, Brazil

E-mail: $\underline{d m f s @ p o w e r . u f s c a r . b r}$

\section{Dedicated to Professor Otto R. Gottlieb on this $85^{\text {th }}$ birthday}

(received 19 Apr 04; accepted 06 July 04; published on the web 18 July 04)

\begin{abstract}
The roots of Toona ciliata yielded four new 9,10-dihydrophenanthrenes which were identified on the basis of spectroscopic analysis as 9,10-dihydro-9-hydroxy-9-(tert-butoxycarbonylmethyl)10-oxophenanthrene, 9,10-dihydro-9-hydroxy-9-(ethoxycarbonylmethyl)-10-oxophenanthrene, 9,10-dihydro-9-hydroxy-9-(n-butoxycarbonylmethyl)-10-oxophenanthrene and 9,10-dihydro-9hydroxy-9-(benzyloxycarbonylmethyl)-10-oxophe-nanthrene. These compounds represent a novel group of phenanthrenes lacking oxygen in the benzene rings. In addition the known limonoid cedrelone, the sterols sitosterol and stigmasterol, the coumarins isopimpinellin and siderin, the furoquinoline alkaloid skimmianine and 2-hydroxy-4-methoxycinnamaldehyde were also isolated and characterized.
\end{abstract}

Keywords: Toona ciliate, Meliaceae, 9,10-dihydrophenanthrenes, limonoid, biochemical systematics

\section{Introduction}

The genus Toona (Endlicher) M. J. Roemer contains approximately six poorly defined species which occur in the old world eastwards from Indian to Australia. ${ }^{1}$ Phytochemical data are available for T. sureni (Blume) Merril. and T. ciliata M. J. Roem. The latter has been the more widely investigated and is a major source of ring-B-seco limonoids. ${ }^{2-7}$ Furthermore, it produces sesquiterpenes of the cadinene group, ${ }^{8,9} \alpha$ - and $\beta$ - amyrins acylated with fatty acids, ${ }^{5}$ simple coumarins $^{5}$ and proanthocyanidins. ${ }^{10}$ The constituents of $T$. sureni are so far four limonoids with intact carbon squeleton ${ }^{11}$ and ring-A/ring-B dilactones. ${ }^{12}$ Toona was originally described by 
Endlicher ${ }^{1}$ as a section of Cedrela. However, Roemer later recognized that they could be separated by a number of sound morphological characters, raising Toona to generic rank. ${ }^{1}$ The known limonoids from Cedrela are mainly mexicanolides. ${ }^{5}$ Thus, the total lack of mexicanolides in all aerial parts of $T$. ciliata strongly supports Roemer's taxonomic conclusions. We have now examined the roots since they have never been investigated before and in order to determine if the above differences still remain also in this organ.

\section{Results and Discussion}

The dichloromethane extract from the roots of exotic T. ciliata, afforded the limonoid cedrelone, ${ }^{5}$ the sterols sitosterol and stigmatesrol, the coumarins isopimpinellin and siderin, ${ }^{5}$ the furoquinoline alkaloid skimmianine, 2-hydroxy-4-methoxycinnamaldehyde and four 9,10dihydrophenanthrenes 1-4 (Figure 1).
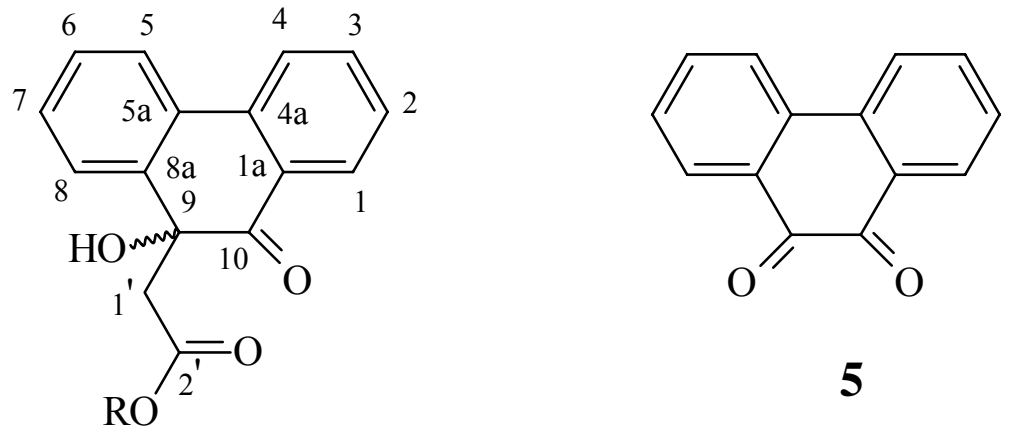

$$
\begin{aligned}
& \text { 1: } \mathrm{R}=\stackrel{\text { 1" }}{\mathrm{C}}\left(\mathrm{CH}_{3}\right)_{3} ; \quad 2: \mathrm{R}=\stackrel{\text { " }}{\mathrm{C}} \stackrel{2 "}{\mathrm{C}_{2}} \mathrm{CH}_{3} \\
& \text { 3: } \mathrm{R}=\stackrel{\text { 1" }}{\mathrm{C}} \mathrm{C}_{2} \mathrm{CH}_{2} \mathrm{CH}_{2} \stackrel{\text { 4" }}{\mathrm{C}} \mathrm{H}_{3} ; \quad 4: \mathrm{R}=\stackrel{1 "}{\mathrm{C}} \mathrm{H}_{2} \mathrm{Ph}
\end{aligned}
$$

\section{Figure 1}

The major compound was identified as $\mathbf{1}$ on the basis of the following data. EI mass spectrometry gave $[\mathrm{M}]^{+}$as $\mathrm{C}_{20} \mathrm{H}_{20} \mathrm{O}_{4}$ and the IR spectrum indicated carbonyl, ester carbonyl, and hydroxyl functional groups. The ${ }^{1} \mathrm{H}$ NMR spectrum run in $\mathrm{C}_{6} \mathrm{D}_{6}$ (Table 1) was better resolved than in $\mathrm{CDCl}_{3}$ and showed signals integrating for eight aromatic protons. The ${ }^{1} \mathrm{H}-{ }^{1} \mathrm{H}$ COSY and homonuclear decoupling experiments suggested the presence of two ortho disubstituted phenyl rings. One ring was established by the four mutually-coupled proton system at $\delta 7.88$ ( $d d d, J=$ 7.4, 1.6, $0.4 \mathrm{~Hz}), 7.06(t d, J=7.4,1.4 \mathrm{~Hz}), 7.02(t d, J=7.4,1.6 \mathrm{~Hz}), 7.36(d d d, J=7.4,1.4,0.4$ $\mathrm{Hz})$. 
Table 1. ${ }^{1} \mathrm{H}$ NMR chemical shifts for compounds 1-5

\begin{tabular}{|c|c|c|c|c|c|}
\hline $\mathrm{H}$ & $\mathbf{1}\left(\mathrm{C}_{6} \mathrm{D}_{6}\right)$ & $2\left(\mathrm{C}_{6} \mathrm{D}_{6}\right)$ & $\mathbf{3}\left(\mathrm{CDCl}_{3}\right)$ & $4\left(\mathrm{C}_{6} \mathrm{D}_{6}\right)$ & $\mathbf{5}\left(\mathrm{CDCl}_{3}\right)$ \\
\hline 1 & $\begin{array}{c}8.00 d d d \\
(7.5,1.5,0.5)\end{array}$ & $\begin{array}{c}8.00 d d d \\
(7.5,1.4,0.5)\end{array}$ & $\begin{array}{l}7.93 d \\
(7.6)\end{array}$ & $\begin{array}{c}7.89 d d \\
(7.6,1.5)\end{array}$ & $\begin{array}{c}8.08 \text { br d } \\
(8.0)\end{array}$ \\
\hline 2 & $\begin{array}{c}6.93 t d \\
(7.5,1.0)\end{array}$ & $\begin{array}{c}6.93 \mathrm{td} \\
(7.5,1.0)\end{array}$ & $7.40-7.47 \mathrm{~m}$ & $\begin{array}{c}6.88 \mathrm{td} \\
(7.6,1.0)\end{array}$ & 7.80 app. $t$ \\
\hline 3 & $\begin{array}{c}7.10 d d d \\
(8.0,7.5,1.5)\end{array}$ & $\begin{array}{c}7.10 \mathrm{ddd} \\
(7.9,7.5,1.4)\end{array}$ & $\begin{array}{c}7.70 \mathrm{td} \\
(7.6,1.6)\end{array}$ & $\begin{array}{c}7.08 t d \\
(7.6,1.5)\end{array}$ & 7.55 app. $t$ \\
\hline 4 & $\begin{array}{c}7.37 d d d \\
(8.0,1.0,0.5)\end{array}$ & $\begin{array}{c}7.38 d d d \\
(7.9,1.0,0.5)\end{array}$ & $\begin{array}{l}7.91 d \\
(7.6)\end{array}$ & $\begin{array}{c}7.35 d d \\
(7.4,1.5)\end{array}$ & $\begin{array}{c}8.25 d d \\
(7.8,1.3)\end{array}$ \\
\hline 5 & $\begin{array}{c}7.36 d d d \\
(7.4,1.4,0.4)\end{array}$ & $\begin{array}{c}7.37 d d d \\
(7.4,1.5,0.4)\end{array}$ & $7.79-7.84 \mathrm{~m}$ & $\begin{array}{c}7.35 d d \\
(7.4,1.5)\end{array}$ & $\begin{array}{c}8.25 d d \\
(7.8,1.3)\end{array}$ \\
\hline 6 & $\begin{array}{c}7.02 t d \\
(7.4,1.6)\end{array}$ & $\begin{array}{c}7.03 t d \\
(7.4,1.9)\end{array}$ & $7.40-7.47 \mathrm{~m}$ & $\begin{array}{c}7.02 \mathrm{td} \\
(7.4,1.9)\end{array}$ & 7.55 app. $t$ \\
\hline 7 & $\begin{array}{c}7.06 t d \\
(7.4,1.4)\end{array}$ & $\begin{array}{c}7.07 t d \\
(7.4,1.5)\end{array}$ & $7.40-7.47 \mathrm{~m}$ & $7.05 \mathrm{~m}$ & 7.80 app. $t$ \\
\hline 8 & $\begin{array}{c}7.88 d d d \\
(7.4,1.6,0.4)\end{array}$ & $\begin{array}{c}7.87 d d \\
(7.4,1.9)\end{array}$ & $7.79-7.84 \mathrm{~m}$ & $\begin{array}{c}7.84 d d \\
(7.4,1.9)\end{array}$ & $\begin{array}{c}8.08 \mathrm{brd} \\
(8.0)\end{array}$ \\
\hline 1'a & $\begin{array}{l}2.72 d \\
(14.1)\end{array}$ & $\begin{array}{l}2.74 d \\
(14.2)\end{array}$ & $\begin{array}{l}2.85 d \\
(14.0)\end{array}$ & $\begin{array}{l}2.74 d \\
(14.3)\end{array}$ & \\
\hline $1^{\prime} b$ & $\begin{array}{l}2.62 d \\
(14.1)\end{array}$ & $\begin{array}{l}2.63 d \\
(14.2)\end{array}$ & $\begin{array}{l}2.79 d \\
(14.0)\end{array}$ & $\begin{array}{l}2.61 d \\
(14.3)\end{array}$ & \\
\hline 1 "a & & $\begin{array}{c}3.79 d q \\
(18.4,7.2)\end{array}$ & $3.99 \mathrm{~m}$ & $\begin{array}{l}4.85 d \\
(12.3)\end{array}$ & \\
\hline $1 " \mathrm{~b}$ & & $\begin{array}{c}3.77 d q \\
(18.4,7.2)\end{array}$ & $3.99 \mathrm{~m}$ & $\begin{array}{l}4.80 d \\
(12.3)\end{array}$ & \\
\hline $2 "$ & $1.28 \mathrm{~s}(3 \mathrm{Me})$ & $\begin{array}{l}0.84 t \\
(7.2)\end{array}$ & $\begin{array}{c}1.53 \text { br quint } \\
\text { (7.2) }\end{array}$ & & \\
\hline $3 "$ & & & $\begin{array}{c}1.30 \mathrm{br} \mathrm{sext} \\
(7.2)\end{array}$ & & \\
\hline $4 "$ & & & $\begin{array}{l}0.90 t \\
(7.2)\end{array}$ & & \\
\hline $\begin{array}{c}3 "-7 " \\
10- \\
\mathrm{OH}\end{array}$ & $4.71 \mathrm{brs}$ & $4.60 \mathrm{br} \mathrm{s}$ & $4.47 \mathrm{~s}$ & $\begin{array}{c}7.05-7.08 \mathrm{~m} \\
4.67 \mathrm{br} \mathrm{s}\end{array}$ & \\
\hline
\end{tabular}

Resonances in 1 were confirmed by ${ }^{1} \mathrm{H}-{ }^{1} \mathrm{H}$ COSY, HMBC and homonuclear decoupling experiments. Coupling constants $(\mathrm{Hz})$ in parentheses.

Some small aromatic para coupling were obscured by line broadening. 
Another sequence consisted of a downfield-shifted proton signal at $\delta 8.00(d d d, J=7.5,1.5$, $0.5 \mathrm{~Hz}$ ) which was coupled to the ${ }^{1} \mathrm{H}$ signals at $\delta 6.93(t d, J=7.5,1.0 \mathrm{~Hz}), 7.10(d d d, J=8.0$, $7.5,1.5 \mathrm{~Hz}$ ) and $7.37(d d d, J=8.0,1.0,0.5 \mathrm{~Hz}$ ), requiring one of the carbonyl substituents to be attached to this second ring and permitting the assignment of the signal at $\delta 8.00$ to $\mathrm{H}-1$. This was supported by the HMBC experiments (see Experimental) which showed correlations between this latter proton signal and the ${ }^{13} \mathrm{C}$ signal at $\delta 201.9\left({ }^{3} \mathrm{~J}\right)$. The ${ }^{1} \mathrm{H}$ signal at $\delta 6.93$ was ortho-coupled to the H-1 signal and showed a cross peak with the singlet resonance at $\delta 129.8$ $\left(J^{3}\right)$, thus these signals can be attributed to $\mathrm{H}-2$ and $\mathrm{C}-1$ a adjacent to the ketonic carbonyl group ( $\delta$ 201.9), respectively. The proton signal at $\delta 7.37$ was para-coupled to the $\mathrm{H}-1$ signal (then assigned to $\mathrm{H}-4$ ) and showed long-range correlation with the ${ }^{13} \mathrm{C}$ signal at $\delta 129.7$. The ${ }^{1} \mathrm{H}$ signal at $\delta 7.36$ belonging to another phenyl ring, also showed long-range correlation with the ${ }^{13} \mathrm{C}$ signal at $\delta 129.7$. If the latter signal was assigned to a carbon belonging to the second ring and shows cross peaks by ${ }^{3} J$ with the $\mathrm{H}-4$, both rings must be bound to each other. Thus, the above correlations permitted the assignments of $\mathrm{H}-5$ at $\delta 7.36$ and C-5a at $\delta 129.7$. Furthermore, the observed correlations between the quaternary oxygen-bearing carbon at $\delta 78.2$ and the ${ }^{1} \mathrm{H}$ signal at $\delta 7.88$, which was para-coupled to the H-5, indicated a quaternary benzyl alcohol to be located at $\mathrm{C}-8 \mathrm{a}$ and led to their assignments as $\mathrm{C}-9$ and $\mathrm{H}-8$, respectively. The ${ }^{1} \mathrm{H}$ NMR also showed one isolated AB-type methylene at $\delta 2.62$ and 2.72. The correlation from the latter signal to the C-9 signal and to two carbonyl signals at $\delta 201.9$ and 167.8, resulted in the construction of an atypical 9,10-dihydro-9-hydroxy-9-(alkoylcarbonylmethyl)-10-oxophenanthrene system, lacking oxygen in the benzene rings. A tert-butoxide group must be connected at carbonyl carbon due to the observed correlation between a singlet at $\delta 1.28(9 \mathrm{H}$, assigned to three magnetically equivalent methyl groups) and the ${ }^{13} \mathrm{C}$ signal at $\delta 81.0$. The large geminal coupling constant of the methylene protons was consistent with C-9 fully substituted. The identification of the nucleus as a 9-hydroxy-10-oxophenanthrene was also supported by the mass spectrum which gave a significant fragment at m/z 209 (Scheme 1) due to fission of the side chain between C-1' and C-9. The structure of the new natural product was thus established as 9,10-dihydro-9-hydroxy-9-(tertbutoxycarbonylmethyl)-10-oxophenanthrene (1).

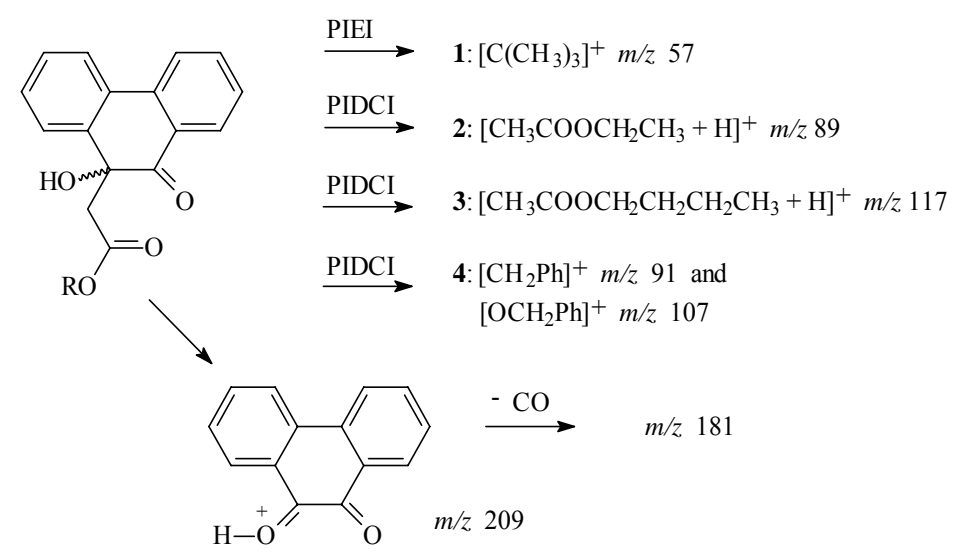

Scheme 1. Fragmentation pathway of compounds 1 - 4. 
The structural assignment was also confirmed by comparison of the ${ }^{1} \mathrm{H}$ and ${ }^{13} \mathrm{C}$ NMR spectra (Table 1 and 2) with those of synthetic phenanthrenequinone (5). ${ }^{13}$

Table 2. ${ }^{13} \mathrm{C}$ NMR chemical shift for compounds 1-5

\begin{tabular}{cccccc}
\hline $\mathrm{C}$ & $\mathbf{1}\left(\mathrm{C}_{6} \mathrm{D}_{6}\right)$ & $\mathbf{2}\left(\mathrm{C}_{6} \mathrm{D}_{6}\right)$ & $\mathbf{3}\left(\mathrm{CDCl}_{3}\right)$ & $\mathbf{4}\left(\mathrm{C}_{6} \mathrm{D}_{6}\right)$ & $\mathbf{5}\left(\mathrm{CDCl}_{3}\right)$ \\
\hline 1 & 127.9 & 128.0 & 127.7 & 128.0 & 130.4 \\
2 & 128.6 & 128.6 & 128.8 & 128.7 & 129.5 \\
3 & 134.4 & 134.4 & 135.0 & 134.4 & 135.9 \\
4 & 123.1 & 123.1 & 123.2 & 123.0 & 123.9 \\
5 & 124.4 & 124.3 & 124.3 & 124.4 & 123.9 \\
6 & 128.5 & 128.3 & 128.8 & 128.5 & 135.9 \\
7 & 129.5 & 129.4 & 129.5 & 129.4 & 129.5 \\
8 & 126.7 & 126.6 & 126.1 & 126.6 & 130.4 \\
9 & 78.2 & 78.0 & 77.7 & 78.0 & 180.2 \\
10 & 201.9 & 201.7 & 202.1 & 201.7 & 180.2 \\
$1 \mathrm{a}$ & 129.8 & 129.7 & 129.3 & 129.7 & 131.0 \\
4a & 137.2 & 137.1 & 136.9 & 137.1 & 135.8 \\
5a & 129.7 & 129.7 & 129.3 & 129.6 & 135.8 \\
8a & 140.6 & 140.3 & 139.3 & 140.2 & 131.0 \\
1' & 50.2 & 49.0 & 48.8 & 48.8 & \\
2" & 167.8 & 168.3 & 169.0 & 168.3 & \\
1" & 81.0 & 60.6 & 64.9 & 66.6 & \\
2" & $27.9(3 \mathrm{Me})$ & 13.9 & 30.4 & 136.1 & \\
3” & & & 19.1 & 128.6 & \\
4" & & & 13.7 & 128.3 & \\
5” & & & & 128.2 & \\
6" & & & & 128.3 & \\
7” & & & & 128.6 & \\
\hline
\end{tabular}

Assignments based on HMQC and HMBC for $\mathbf{1}$ and DEPT 135 for 2-4

Compound 2 exhibited similar spectra data to 1 (Table 1 and 2). The ${ }^{1} \mathrm{H}$ NMR spectrum, instead of signals for a tert-butoxide group, showed signals for a methyl triplet $(\delta 0.84, J=7.2)$ and ${ }^{1} \mathrm{H}$ resonances for an $\mathrm{AB}$ system associated with a methylene group whose hydrogens were not equivalent and each make up an $\mathrm{AB}$ doublet $(J=18.4)$ further split by additional coupling with the methyl-hidrogens $(J=7.2)$. A significant fragment at $m / z 89\left[\mathrm{CH}_{3} \mathrm{COOCH}_{2} \mathrm{CH}_{3}+\mathrm{H}\right]$ in the mass spectrum for 2 , associated with retro-aldol cleavage of side-chain, clearly indicated the presence of a carboethoxy group at C-1' (Scheme 1). Thus, compound 2 was concluded to be 9,10-dihydro-9-hydroxy-9-(ethoxycarbonylmethyl)-10-oxophenanthrene. Compounds $\mathbf{1}$ and $\mathbf{2}$ 
have already been known as a reaction product obtained from phenanthrenequinone (5), ${ }^{14-16}$ however, this the first time that they have been isolated as natural products.

Compound 3 was isolated in very small amounts and could not be separated from 2 . This mixture gave rise to a mass spectrum which indicated a molecular formula $\mathrm{C}_{20} \mathrm{H}_{20} \mathrm{O}_{4}\left([\mathrm{M}+\mathrm{H}]^{+}=\right.$ 325 ) for 3 , suggesting an isomer of $\mathbf{1}$. Analysis of the ${ }^{1} \mathrm{H} \mathrm{NMR}$, which in addition to signals described above for 2 showed a broad quintet at $\delta 1.53$ and a broad sextet at $\delta 1.30$, together with the signals at $\delta 64.9$ (C-1"), 30.4 (C-2"), 19.1 (C-3") and 13.7 (C-4") in the ${ }^{13} \mathrm{C}$ NMR, indicated the alcohol portion to be $n$-butyl. Moreover, the chemical shifts of $n$-butyl carbons were comparable with those reported for O-alkyl group in $n$-butyl ethanoate $(\delta 63.1,30.4,18.6$ and 12.7). ${ }^{17}$ In addition, compound 3 did not give a significant fragment at $m / z 57$ as in $\mathbf{1}$, the ion observed being $\mathrm{m} / \mathrm{z} 117$ for $\left[\mathrm{CH}_{3} \mathrm{COOCH}_{2} \mathrm{CH}_{2} \mathrm{CH}_{2} \mathrm{CH}_{3}+\mathrm{H}\right]^{+}$. These data were consistent with the structure of 9,10-dihydro-9-hydroxy-9-(n-butoxycarbonylmethyl)-10-oxophenanthrene for 3.

Compound 4 also showed the spectral characteristics of a 9,10-dihydro-9-hydroxy-9(alkoylcarbonylmethyl)-10-oxophenanthrene system. The mass spectrum gave significant fragments for $\mathrm{m} / \mathrm{z} 107$ and 91 (Scheme 1) requiring the presence of a benzyloxyl group. The ${ }^{1} \mathrm{H}$ NMR spectrum of 4 (Table 1) revealed that the phenanthrene rings resonances remain essentially unchanged. However, eight protons occurred as a complex multiplet between $\delta 6.99$ and 7.10, three of which belonged to H-3 $(\delta 7.08 d t)$, H-6 $(\delta 7.02 d t)$ and H-7 $(\delta 7.05 \mathrm{~m})$ and the other five ( $\left.\delta 7.05-7.08 \mathrm{~m} ; 3^{\prime \prime}-7 "\right)$ clearly indicated the unsubstituted nature of the benzyloxyl group. The indication of the alcohol portion of the new ester received further support from the ${ }^{13} \mathrm{C} N M R$ spectrum (Table 2) which showed close agreement with published data for this group in 2'hydroxy-4',6',3-trimethoxy-4-benzyloxychalcone. ${ }^{18}$ Therefore, the structure of $\mathbf{4}$ was assumed to be 9,10-dihydro-9-hydroxy-9-(benzyloxycarbonylmethyl)-10-oxophenanthrene.

This appears to be the first record of phenanthrenes from Meliaceae or from the allied families of the order Rutales (Rutaceae, Meliaceae, Simaroubaceae and Cneoraceae). In addition, these compounds represent a novel group of unsubstituted phenanthrenes. Oxidation involving

phenyl rings, as hydroxyl and methoxyl substituents, has been found in Orchidaceae. ${ }^{13}$ It can of course be argued that the roots were collected with a trace of other roots which do not belong to T. ciliata. However, subsequent to this work we ourselves have found these compounds in stock of a 5-year-old tree of C. odorata grafted on T. ciliata. ${ }^{19}$ Indeed the sporadic occurrence of particular micromolecular types in unrelated taxa is a general phenomenon. ${ }^{20}$

\section{Experimental Section}

General Procedures. NMR: on a Bruker DRX 400, with TMS as int. standard; the twodimensional (2D) experiments were acquired and processed with software provided by Bruker on an Aspect X32 computer; standard pulse sequences were used for ${ }^{1} \mathrm{H} \mathrm{x}{ }^{1} \mathrm{H}-\mathrm{COSY}$ (pulse angle $45^{\circ}$, spectral width $8000 \mathrm{~Hz}, 1 \mathrm{~K} \times 128$ acquisition and $1 \mathrm{~K}$ × 512 processed) spectra; twodimensional inverse hydrogen detected heteronuclear shift correlation ${ }^{1} \mathrm{H} x{ }^{13} \mathrm{C}-\mathrm{HMQC}-{ }^{1} J(\mathrm{C}, \mathrm{H})$ 
spectra were obtained with the INVBTP program $\left[{ }^{1} J(C, H)=145 \mathrm{~Hz}, f_{2} 30118 \mathrm{~Hz}, f_{1} 8012 \mathrm{~Hz}\right.$, relaxation delay $2.0 \mathrm{~s}]$; two-dimensional inverse hydrogen detected heteronuclear long-range correlation ${ }^{1} \mathrm{H} \mathrm{x}{ }^{13} \mathrm{C}-\mathrm{HMBC}-{ }^{n} J(\mathrm{C}, \mathrm{H})(\mathrm{n}=2$ and 3$)$ experiments were carried out by using the INVBTP program [polarization delay $52 \mathrm{~ms},{ }^{n} J(\mathrm{C}, \mathrm{H})=7 \mathrm{~Hz}, f_{2} 30120 \mathrm{~Hz}, f_{1} 8012 \mathrm{~Hz}$, relaxation delay $2.0 \mathrm{~s}$. PIEIMS and PIDCIMS: low resolution on a VG Plataform II (Fisons) instrument; $[\alpha]_{D}$ : Perkin Elmer 241 instrument; IR (KBr, BOMEN - Ft/IR ); UV (Perkin-Elmer); R-HPLC: Recycling High-Performance Liquid Chromatography on a model Shimadzu LC-6AD; the column used was a Shim-pack Prep-Sil (H), $250 \mathrm{~mm} \mathrm{X} 20 \mathrm{~mm}, 5 \mu \mathrm{m}$ particle size, $100 \mathrm{~A}^{0}$ pore diameter; eluant: $\mathrm{CHCl}_{3}$; flow rate: $8.0 \mathrm{ml} / \mathrm{min}$ and $5.0 \mathrm{ml} / \mathrm{min}$; detection (Shimadzu SPD6AV): UV $\lambda 254 \mathrm{~nm}$.

Plant material. T. ciliata var. australis was collected in Viçosa, M.G., Brazil, and a voucher is deposited in the Herbarium of the Departamento de Engenharia Florestal, Universidade Federal de Viçosa, Viçosa, M.G.

Isolation of compounds. The roots were dried, powdered (1050 g) and extracted with hexane, then $\mathrm{CH}_{2} \mathrm{Cl}_{2}, \mathrm{MeOH}$ and finally with $\mathrm{H}_{2} \mathrm{O}$. Preliminary examination of the two first extracts using TLC (silica gel) showed each to contain the same range of compounds, so they were combined $(418.3 \mathrm{mg})$. During concentration of the combined extracts a crystalline material separated which was collected and crystallised from $\mathrm{MeOH}$ to give cedrelone as colourless prisms $(37.5 \mathrm{mg})$. The concd hexane- $\mathrm{CH}_{2} \mathrm{Cl}_{2}$ extract was flash chromatographed on silica gel eluting with a hexane- $\mathrm{CH}_{2} \mathrm{Cl}_{2}-\mathrm{MeOH}$ gradient affording a mixture of sterols and 7 frs. The mixture of sterols was analysed by GC-mass spectrometry, which established that the sterols were sitosterol and stigmasterol. Fr. 2 yielded, after crystallization in $\mathrm{MeOH}$, siderin as colourless needles $(10.3 \mathrm{mg}$ ). Fr. 3 was submitted to R-HPLC (detection UV $\lambda 254 \mathrm{~nm}$, flow rate: $5.0 \mathrm{ml} / \mathrm{min}$ ) affording 2-hydroxy-4-methoxycinnamaldehyde (2nd peak, $8.6 \mathrm{mg}$ ), after recycling $\times 3$. Fr. 6 was also submitted to R-HPLC (flow rate: $8.0 \mathrm{ml} / \mathrm{min}$ ) as above affording isopimpinellin (1st peak, $5.0 \mathrm{mg}$ ) and skimmianine (2nd peak, $7.0 \mathrm{mg}$ ), after recycling x 3. Fr. 7 yielded a ppt. which was removed and dissolved in $\mathrm{EtOH}-\mathrm{Me}_{2} \mathrm{CO}$ (9:1) and kept in the refrigerator overnight; compound $2(29.3 \mathrm{mg})$ separated. The filtrate was evaporated and the residue was repeatedly purified by prep. TLC yielding a mixt. $(3 \mathrm{mg})$ of 2 and 3 . The mother liquor of Fr. 7 was flash chromatographed on silica gel by isocratic elution with $\mathrm{CH}_{2} \mathrm{Cl}_{2}$ affording $\mathbf{1}(43.6 \mathrm{mg})$ and $\mathbf{4}(38.5 \mathrm{mg})$.

9,10-Dihydro-9-hydroxy-9-(tert-butoxycarbonylmethyl)-10-oxophenanthrene (1). Amorphous solid, mp 248-251 ${ }^{0},[\alpha]_{\mathrm{D}}+0.2^{0}\left(\mathrm{CH}_{2} \mathrm{Cl}_{2}\right.$; c 0.01). UV $\lambda_{\max }\left(\mathrm{CH}_{2} \mathrm{Cl}_{2}\right) \mathrm{nm}: 243,278,325 ; \mathrm{IR} v_{\max }$ $(\mathrm{KBr}) \mathrm{cm}^{-1}: 3478,1723,1687 .{ }^{1} \mathrm{H}$ NMR $\left(400 \mathrm{MHz}, \mathrm{C}_{6} \mathrm{D}_{6}\right)$ : Table $1 ;{ }^{13} \mathrm{C}$ NMR $\left(100 \mathrm{MHz}, \mathrm{C}_{6} \mathrm{D}_{6}\right)$ : Table 2; HMBC (400 MHz, $\left.\mathrm{C}_{6} \mathrm{D}_{6}\right)$ : H-1 $\rightarrow$ C-2, C-3, C-10; H-2 $\rightarrow$ C-1a, C-4; H-3 $\rightarrow$ C-1, C-4a; $\mathrm{H}-4 \rightarrow \mathrm{C}-1 \mathrm{a}, \mathrm{C}-5 \mathrm{a} ; \mathrm{H}-5 \rightarrow \mathrm{C}-5 \mathrm{a} ; \mathrm{H}-6 \rightarrow \mathrm{C}-8$; H-7 $\rightarrow$ C-5, C-8a; H-8 $\rightarrow$ C-9; H-1'a $\rightarrow$ C-2', C-9, $\mathrm{C}-10, \mathrm{C}-11 ; \mathrm{H}-1$ 'b $\rightarrow$ C-2', C-11; 3Me $\rightarrow$ C-1". PEIMS m/z (rel. int.): 324 [M ] ${ }^{+}$(2), 268 (15), 209 (100), 181 (90), $152(35), 57$ (70). 
9,10-Dihydro-9-hydroxy-9-(ethoxycarbonylmethyl)-10-oxophenanthrene (2). Amorphous solid, mp 238-241 ${ }^{0},[\alpha]_{\mathrm{D}}+28.6^{0}\left(\mathrm{CH}_{2} \mathrm{Cl}_{2} ; \mathrm{c}\right.$ 0.0002). UV $\lambda_{\max }\left(\mathrm{CH}_{2} \mathrm{Cl}_{2}\right) \mathrm{nm}$ : 243, 278, 325; IR $v_{\max }(\mathrm{KBr}) \mathrm{cm}^{-1}: 3515,1726,1693 .{ }^{1} \mathrm{H}$ NMR $\left(400 \mathrm{MHz}, \mathrm{C}_{6} \mathrm{D}_{6}\right)$ : Table $1 ;{ }^{13} \mathrm{C} \mathrm{NMR}(100 \mathrm{MHz}$, $\mathrm{C}_{6} \mathrm{D}_{6}$ ): Table 2. PDCIMS m/z (rel. int.): $297\left[\mathrm{M}+\mathrm{H}^{+}\right.$(10), $279\left[\mathrm{M}+\mathrm{H}-\mathrm{H}_{2} \mathrm{O}\right]^{+}$(50), 209 (100), $181(80), 152$ (40), 89 (60).

9,10-Dihydro-9-hydroxy-9-(n-butoxycarbonylmethyl)-10-oxophenanthrene (3, with trace of 2). Amorphous solid; ${ }^{1} \mathrm{H} \mathrm{NMR}\left(400 \mathrm{MHz}, \mathrm{CDCl}_{3}\right)$ : Table $1 ;{ }^{13} \mathrm{C} \mathrm{NMR}\left(100 \mathrm{MHz}, \mathrm{CDCl}_{3}\right)$ : Table 2. The PDCIMS $\mathrm{m} / \mathrm{z}$ in addition to fragments described above for 2 , revealed the following peaks: $325[\mathrm{M}+\mathrm{H}]^{+}(5), 307\left[\mathrm{M}+\mathrm{H}-\mathrm{H}_{2} \mathrm{O}\right]^{+}$(15), 209 (100), 181 (80), 152 (25), 117 (50).

9,10-Dihydro-9-hydroxy-9-(benzyloxycarbonylmethyl)-10-oxophenanthrene (4). Amorphous solid, mp 271-275 ${ }^{0},[\alpha]_{\mathrm{D}}-0.4^{0}\left(\mathrm{CH}_{2} \mathrm{Cl}_{2} ; \mathrm{c}\right.$ 0.004). UV $\lambda_{\max }\left(\mathrm{CH}_{2} \mathrm{Cl}_{2}\right) \mathrm{nm}: 278$, 326; IR $v_{\max }$ $(\mathrm{KBr}) \mathrm{cm}^{-1}: 3473,1735,1694 .{ }^{1} \mathrm{H}$ NMR (400 MHz, $\left.\mathrm{C}_{6} \mathrm{D}_{6}\right)$ : Table $1 ;{ }^{13} \mathrm{C}$ NMR $\left(100 \mathrm{MHz}, \mathrm{C}_{6} \mathrm{D}_{6}\right)$ : Table 2. PDCIMS m/z (rel. int.): $359[\mathrm{M}+\mathrm{H}]^{+}$(2), $341\left[\mathrm{M}+\mathrm{H}-\mathrm{H}_{2} \mathrm{O}\right]^{+}$(3), 235 (15), 209 (25), 181 (40), 107 (65), 91 (100).

\section{Acknowledgements}

The authors thank Conselho Nacional de Desenvolvimento Científico e Tecnológico (CNPq), Fundação de Amparo à Pesquisa do Estado de São Paulo (FAPESP), Coordenação de Aperfeiçoamento de Pessoal de Ensino Superior (CAPES) and Financiadora de Estudos e Projetos (FINEP) for the financial support.

\section{References}

1. Pennington, T. D.; Styles, B. T. Blumea 1975, 22, 419.

2. Banerji, R.; Mitra, C. R. Planta Medica 1975, 28, 52.

3. Chatterjee, A.; Chakrabortty, T.; Chandrasekharan, S. Phytochemistry 1971, 10, 2533.

4. Kraus, W.; Grimminger, W. Nouveau Journal de Chimie 1980, 4, 651.

5. Agostinho, S. M. M.; Silva, M. F. das G. F. da; Fernandes, J. B.; Vieira, P. C.; Pinheiro, A. L.; Vilela, E. F. Biochemical Systematics and Ecology 1994, 22, 323.

6. Oiano-Neto, J.; Agostinho, S. M. M.; Silva, M. F. das G. F. da; Fernandes, J. B.; Vieira, P. C.; Pinheiro, A. L.; Vilela, E. F. Phytochemistry 1995, 38, 397.

7. Oiano-Neto, J.; Silva, M. F. das G. F. da; Rodrigus Fo, E.; Fernandes, J. B.; Vieira, P. C.; Pinheiro, A. L. Phytochemistry 1998, 49, 1369.

8. Nagasampagi, B. A.; Yankov, L.; Dev, S. Tetrahedron Lett. 1968, 1913.

9. Takeoka, G.; Flath, R. A.; Mon, T. R.; Buttery, R. G.; Teranish, R.; Güntert, M.; Lautamo, R.; Szejtli, F. Journal of High Resolution Chromatography 1990, 13, 202.

10. Bhatia, V. K.; Madhav, R.; Seshadri, T. R. Indian Journal of Chemistry 1969, 7, 121. 
11. Kraus, W.; Kypke, K. Tetrahedron Lett. 1979, 2715.

12. Kraus, W.; Kypke, K.; Bokel, M.; Grimminger, W.; Sawitzki, G.; Schwinger, G. Liebigs Annalen 1982, 87.

13. Majumder, P. L.; Sen, R. C. Phytochemistry 1991, 30, 2092.

14. Nair, V.; Jayan, C. N.; Ros, S. Tetrahedron 2001, 57, 9453.

15. Cameron, D. W.; Deutscher, K. R.; Feutrill, G. I. Austral. J. of Chem. 1978, 31, 2259.

16. Rivel, V.; Soto, V. H.; Ciccio, J. F. Ingenieria y Ciencia Quimica 2000, 19, 59.

17. Breitmaier, E.; Voelter, W. Carbon-13 NMR Spectroscopy: high resolution methods and applications in organic chemistry and biochemistry; VCH Verlagsgesellschaft: Weinheim 1987.

18. Agrawal, P. K. Carbon-13 NMR of Flavonoids; Elsevier: New York, 1989.

19. Paula, J. R. de; Vieira, I. J. C.; Silva, M. F. das G. F. da; Rodrigus Fo. E.; Fernandes, J. B.; Vieira, P. C.; Pinheiro, A. L.; Vilela, E. F. Phytochemistry 1997, 44, 1449.

20. Silva, M. F. das G. F. da; Gottlieb, O. R. Biochemical Systematics and Ecology 1987, 15, 85. 